\title{
FISCAL ZONING AND SALES TAXES: DO HIGHER SALES TAXES LEAD TO MORE RETAILING AND LESS MANUFACTURING?* \\ Daria Burnes§
}

\author{
David Neumark ${ }^{\dagger}$
}

Michelle J. White

PEP 12

\author{
The Suntory Centre \\ Suntory and Toyota International Centres for \\ Economics and Related Disciplines \\ London School of Economics and Political Science \\ Houghton Street \\ London WC2A 2AE \\ Tel: (020) 79556674
}

\footnotetext{
${ }^{*}$ The authors are grateful to the Public Policy Institute of California and the David A. Coulter Family Foundation for support for using the NETS data for this research. We also thank Tony Soeller for assistance with ArcGIS, Eve Irwin for assistance with the Florida population data and institutional detail, and Sima Kamouie and Linchun Chen for research assistance. The views expressed are not those of the Public Policy Institute of California or the National Bureau of Economic Research. White is grateful to the Cheung Kong Graduate School of Business, Beijing, for hospitality and financial support.

${ }^{\S}$ Daria Burnes, Department of Economics, University of California at Irvine, 3151 Social Science Plaza, Irvine CA 92697-5100. dburnes@uci.edu

${ }^{\dagger}$ David Neumark, Department of Economics, University of California at Irvine, 3151 Social Science Plaza, Irvine, CA 92697 and NBER. dneumark@uci.edu

${ }^{\ddagger}$ Michelle J. White, Department of Economics, University of California, San Diego, La Jolla, CA 92093-0508, and NBER. miwhite@ucsd.edu
} 


\begin{abstract}
We test the hypothesis that local government officials in jurisdictions that have higher local sales taxes are more likely to use fiscal zoning to encourage retailing. We find that total retail employment is not significantly affected by local sales tax rates, but employment in big box and anchor stores is higher significantly in jurisdictions with higher sales tax rates. This suggests that local officials in jurisdictions with higher sales taxes concentrate on attracting large stores and shopping centers. We also find that the effect of local sales taxes on big box and anchor store retail employment is larger in county interiors, where residents tend to be captive to local retailers. Finally, fiscal zoning has the opposite effect on manufacturing employment, suggesting that local officials' efforts to attract shopping centers and large stores crowd out manufacturing.
\end{abstract}




\section{Public Economics Programme}

The Public Economics Programme was established in 2009. It is located within the Suntory and Toyota International Centres for Economics and Related Disciplines (STICERD) at the London School of Economics and Political Science. The programme is directed by Frank Cowell and Henrik Kleven. The Discussion Paper series is available free of charge. To subscribe to the PEP paper series, or for further information on the work of the Programme, please contact our Research Secretary, Leila Alberici on:

Telephone: UK+20 79556674

Fax: $\quad$ UK+20 79556951

Email: 1.alberici@lse.ac.uk

Web site: $\quad$ http://sticerd.lse.ac.uk/PEP provided that full credit, including $\odot$ notice, is given to the source. 


\section{Introduction}

Many U.S. states allow local governments to levy sales taxes that add to the state sales tax and to keep some or all of the revenue (Lewis, 2001). These extra sales taxes give local government officials an incentive to encourage retailing, since retailing generates more sales tax revenue than other land uses. Correspondingly, these taxes also give local government officials an incentive to discourage other land uses, since they generate less sales tax revenue and could crowd out retailing.

Local government officials have various policy instruments and practices that they can use to encourage retailing: they can zone additional land for retail use, they can allow land zoned for retailing to be developed at higher density levels, and they can reduce the often-formidable set of approvals and inspections that are required for construction or renovation. They can use all of the same policy instruments and practices in reverse to discourage other land uses. We use the term "fiscal zoning" to refer to local government officials encouraging land uses that generate high tax revenue-which in this case we interpret as high sales tax revenue. In this paper, we test the hypothesis that local government officials in jurisdictions that have higher local sales taxes are more likely to use fiscal zoning to encourage retailing. We do so by examining whether retail employment in these jurisdictions increases in response to higher sales tax rates.

Manufacturing tends to compete with retailing for land, because both use locations with similar characteristics. ${ }^{1}$ But manufacturing generates less sales tax revenue than retailing because sales taxes are levied only on final sales to consumers, and final sales

\footnotetext{
${ }^{1}$ At least this is likely to be true for large stores and shopping malls, because they occupy large tracts of flat land close to highways-the same characteristics that attract manufacturing. Of course other factors may make specific locations suitable for one use but not the other.
} 
generally do not occur where the manufacturing takes place. ${ }^{2}$ As a result, if local officials favor retailing in order to increase sales tax revenue, the level of manufacturing activity and the number of manufacturing jobs may fall. We therefore also examine whether manufacturing employment falls in jurisdictions where local sales tax rates increase.

Our main finding is that total retail employment is not significantly affected by variation in local sales tax rates. This result is consistent with local governments not using fiscal zoning, but it alternately may occur because the positive effect of fiscal zoning on retail employment is fully offset by the dampening effect of higher sales tax rates on consumer demand. ${ }^{3}$ More consistent with the fiscal zoning hypothesis, we find that higher local sales tax rates lead to more employment in "big box" stores and in department stores that anchor malls. This suggests that local officials concentrate their fiscal zoning efforts on attracting large stores and shopping malls and that they compete more heavily for these if local sales tax rates are higher. The fiscal zoning effect on big box and anchor stores may arise because these stores generate particularly high sales tax revenue or because they are particularly sensitive to local officials' efforts to attract them. We also find that jurisdictions with higher local sales tax rates have lower employment in manufacturing, suggesting that local officials' efforts to attract big box stores and shopping centers crowd out manufacturing.

\footnotetext{
2 See Hawkins and Murray (2004) for evidence that manufacturing generates little or no additional local sales tax revenue. Note that states tend to make some exceptions to the rule that sales taxes are levied only on final sales.

${ }^{3}$ See Mark et al. (2000) for an analysis of the effect of sales taxes and other taxes on economic activity within a single metropolitan area.
} 


\section{Background and Hypotheses}

The hypothesis that local government officials use zoning to choose land uses that increase the local government's revenues and reduce its costs was first proposed by Ohls et al. (1974) and White (1975). They assumed that the main source of revenue for local governments was the property tax and argued that local officials use zoning to select land uses that generate the highest net revenue for the local government, considering both tax revenues and the cost of supplying local public goods. These models imply that local government officials prefer single-family houses over apartments, because single-family houses generate higher property taxes, and prefer commercial and industrial land uses over housing, since non-residential land uses do not raise local governments' costs by increasing enrollment in public schools. ${ }^{4}$

More recently, political scientists have examined local officials' use of zoning to encourage land uses that generate high tax revenues, but with a focus on local sales taxes rather than property taxes. They argue that local officials use zoning to encourage retailing at the expense of other land uses, because retailing brings in the most sales tax revenue. These studies often use California as their setting, since property tax revenues in California have fallen sharply since the late 1970's and local governments there are allowed to adopt local sales taxes. One such study is by Lewis and Barbour (1999), who surveyed city managers in California to determine what type of development they favor and why. They concluded that city managers strongly favor retailing and do so because it generates additional sales tax revenue. But Lewis and Barbour's study failed to examine whether

\footnotetext{
${ }^{4}$ However, commercial and industrial land uses may be undesirable if they generate high pollution or congestion. See Sonstelie and Portney (1978) and Epple and Zelenitz (1981) for formal models of profitmaximizing communities (however their models do not explicitly consider zoning decisions by local government officials). Fischel (1992) provides a general discussion. Gordon and Li (forthcoming) use the assumption of revenue-maximization to examine behavior of local governments in China.
} 
local officials are more likely to use zoning to attract retail activity when sales tax rates are higher, nor did they examine whether officials' efforts were successful. ${ }^{5}$

However, even though incentives for fiscal zoning may exist, we may not observe changes in the composition of economic activity. First, there may be an issue of aggregation. In particular, local governments likely compete against each other to attract concentrations of retail activity such as shopping centers and big box stores. But one location's success in attracting a shopping center is likely to come at the expense of nearby locations, assuming that the area can only support a limited number of shopping centers. Second, while local officials' incentive to attract retailing is stronger when the local sales tax rate is higher, their efforts may be offset by the reduction in demand caused by higher sales tax rates pushing up prices. If the price elasticity of demand is high, then retailers will prefer locations with low or zero local sales tax rates, despite officials' efforts to attract them to locations with high sales tax rates. ${ }^{6}$

Thus while fiscal zoning is expected to result in a positive relationship between local sales tax rates and the amount of retailing, these offsetting effects in fact make the predicted relationship ambiguous and potentially difficult to observe. But finding a positive relationship between changes in local sales tax rates and the level of retail activity would clearly provide evidence of fiscal zoning, since the price effect goes in the opposite direction. We also test the fiscal zoning hypothesis on employment in big box and anchor

\footnotetext{
${ }^{5}$ Studies by political scientists tend to ignore the issue of whether different types of development generate different costs of supplying local public goods-presumably because non-residential land uses generate similar cost levels. For other discussions by political scientists of fiscal zoning and competition for retailing, see Misczynski (1986), Fulton (1998), and Schrag (1998).

${ }^{6} \mathrm{An}$ additional factor is that the price elasticity of demand for goods bought from brick-and-mortar stores has been increasing over time as sales migrate to the internet. See Goolsbee and Zitran (1999).
} 
stores, which are of interest since they both use large amounts of land and produce high levels of sales tax revenue.

Finally, we examine how local sales tax rates affect the level of activity in manufacturing. Manufacturing is a useful sector to look at for a number of reasons. First, fiscal zoning policies that favor retailing are likely to result in declines in manufacturing, because the two uses compete for the same sites. Second, because manufacturing generates little sales tax revenue, higher local sales tax rates do not raise the price of manufacturing output or reduce demand. Thus, unlike the situation in retailing, there is no direct price effect that obscures the predicted effect of fiscal zoning on manufacturing activity. And finally, manufacturing is of interest from a policy standpoint, since local governments' efforts to attract retailing may come at the expense of attracting better-paid jobs in manufacturing (LeRoy, 2005).

\section{Institutional Environment for Local Sales Taxes in Florida}

We use Florida data from 1992-2006 for our study. Florida has a state sales tax, which during our sample period was always 6\%. Counties in Florida can also adopt local sales taxes that are added to the state sales tax. Although property taxes are a more important source of revenue for Florida local governments than local sales taxes, the latter are growing much more rapidly. After correcting for inflation, local sales tax revenue in Florida increased by 380\% between 1992 and 2008, compared to an 8\% increase in property tax revenues (U.S. Census Bureau Census of Governments, 1992 and 2008). Thus, Florida is a good test case for studying the effects of increased reliance on local sales taxes. 
Florida has seven separate local sales taxes. All are levied at the county level and apply uniformly all over the county; the overall local sales tax rate in a county is capped at 1.5\%. Tax revenues from two of these taxes-the infrastructure tax and the small county surtax-go directly to local governments (which in Florida are called municipalities). ${ }^{7}$ These two taxes are the most commonly-used local sales taxes in Florida and they account for most of the revenues. During our sample period, an average of 44 out of 67 Florida counties imposed one or both of these taxes and the average sales tax rate for the two taxes in counties using them was $0.96 \%$. Revenues from these two taxes are distributed to municipalities either based on their shares of county population or on where the sales occurred. For revenues to be distributed according to where sales occurred, the county must adopt an interlocal agreement. ${ }^{8}$ During our sample period, around 35\% of counties that used these two taxes had interlocal agreements (Florida Legislative Committee on Intergovernmental Relations, 2003).

The other five local sales taxes are levied by county-level special-purpose authorities, such as school boards, health or welfare authorities, or transportation authorities. Revenues from these taxes go directly to the authorities that levy them. During our sample period, an average of only eight school boards, two health or welfare authorities, and one transportation authority levied local sales taxes. The average local

\footnotetext{
7 The small county surtax can be used only by counties with populations less than 50,000.

${ }^{8}$ Although county-specific interlocal agreements can be proposed by either the county or the municipal governments, the governing bodies representing the majority of the respective county's municipal population must ultimately approve the agreements.
} 
sales tax rate for these taxes in counties that levied them was $0.48 \%$ during our sample period. See Table 1.A for information on local sales tax rates by type of tax. ${ }^{9}$

Formally, land-use policy in Florida is set at the municipal level, while local sales tax policy is set at the county level. One issue is that officials in most Florida municipalities appear to have little incentive to engage in fiscal zoning, because the sales tax revenue that additional retailing would generate either goes to county-level authorities or is shared among municipalities within a county according to relative population. However counties that adopt local sales taxes clearly have an interest in attracting retailing and county officials have various ways of encouraging municipal officials to adopt zoning policies that favor retailing. One possibility is for the county to adopt an interlocal agreement that distributes revenues from the infrastructure tax or the small county surtax to municipalities based on where retail sales occur. Another possibility is for the county to reward municipalities that adopt fiscal zoning policies by providing them with additional infrastructure. A third possibility is for county officials to engage in fiscal zoning directly by encouraging retail development to occur in unincorporated areas; in these areas counties rather than municipalities are responsible for zoning. ${ }^{10}$

In our empirical work, we ignore the county-municipality distinction and treat counties as though they both decide the local sales tax rate and determine zoning policy. We therefore examine the fiscal zoning hypothesis using county-level data as our unit of

${ }^{9}$ The school board tax is the School Capital Outlay Tax, the transportation tax is the Charter County Transit System Tax, and the health/welfare authority taxes are the Indigent Care and Trauma Center Tax (Dade County only), the County Public Hospital Tax (Dade County only), and the Indigent Care Tax. In addition, there are several other local sales taxes that we exclude from our study, including a tourist development tax, a convention center tax, and a professional sports facility tax. These are excluded because they are imposed on hotels/motels and therefore do not create incentives for local governments to expand retail activity. See Florida Legislative Committee on Intergovernmental Relations (2009 and earlier years).

${ }^{10}$ Municipalities may nonetheless benefit by subsequently annexing the newly-developed land along with nearby areas (e.g., King, 2010; Shoer Roth, 2010). 
analysis. This potentially raises endogeneity concerns, since sales tax rates could be set in response to changes in retail or manufacturing. We examine this issue further and perform tests for endogeneity in Section VI below.

Finally, an important advantage of using Florida data is that counties adopted local sales taxes or changed their rates fairly frequently during our study period. As of 1992, nearly half of Florida counties had no local sales taxes; by 2006, this figure had dropped to 13\%. Also, between 1992 and 2006, there were 75 changes in aggregate local sales tax rates and 32 instances of counties imposing a local sales tax where there was none before. Tables 1.B and 2 give a history of local sales tax rate changes by county over this period. Given that our empirical approach is based on a difference-in-differences analysis relating changes in employment to changes in county tax rates, this extensive within-county variation in sales taxes is essential to identifying the effects of sales taxes.

\section{Data and Approach}

We use panel data from the National Establishment Time Series (NETS) on the universe of individual business establishments in Florida from 1992 to 2006. For each establishment, we know employment each year and the establishment's name and industry. ${ }^{11}$ We aggregate these data to get total employment in retailing by county for each of the 67 Florida counties for each year from 1992 to 2006. Our basic model estimates how changes in local sales tax rates affect retail employment. As discussed in Section II, the predicted sign of this relationship is ambiguous; fiscal zoning tends to make the

\footnotetext{
${ }^{11}$ A detailed discussion of the NETS data along with assessment of its quality is provided in Kolko and Neumark (2007) and Neumark et al. (2007).
} 
relationship positive, but it will be less positive (or more negative) if the price elasticity of retail demand is high and/or if efforts to attract retailing are a zero-sum game.

One question is whether the level of retail employment is well suited to measuring the strength of fiscal zoning. A more direct measure would be the amount of land zoned for retailing. But land zoned for retailing is an imperfect measure of the level of retail activity, both because land zoned for retailing may be vacant and because stores may be vacant. Vacancies of both types may result if local government officials-particularly in high sales tax jurisdictions-zone too much land for retailing. In addition, as noted above, local government officials can also encourage retailing by allowing land zoned for retailing to be developed at higher density levels or by expediting permit and inspection procedures. Using retail employment as our measure of the effect of fiscal zoning has the advantage that it encompasses all three policies and that it measures retail activity only for stores that are actually in operation.

Because large retail concentrations are particularly valuable in areas with higher local sales tax rates, we also examine the effect of fiscal zoning on retail employment in big box stores, such as Wal-Mart, Home Depot, and Costco, and department stores of the type that anchor large shopping malls, such as Macy's. Our hypothesis is that local government officials in jurisdictions that have high local sales taxes are particularly likely to compete for these stores and the associated shopping malls. ${ }^{12}$

\footnotetext{
12 The list of stores we study includes Best Buy, Big Lots, Bloomingdales Inc., Circuit City, Costco, Federated Retail Holdings (Lord \& Taylor), Home Depot, J.C. Penney, K-Mart, Lowes Home Centers, Macy's, May Department Stores, Montgomery Ward, Neiman Marcus Group Inc., Nordstrom Inc., Office Depot, Office Max, Saks \& Company, Sears Roebuck, Staples, Target Corporation, and Wal-Mart. The list of big box retailers is taken from Mazzolari and Neumark (forthcoming) and we added additional stores identified as those that anchor malls in Florida, from Oyston (2007).
} 
We estimate similar models for manufacturing employment. Here the hypothesis is that county-level manufacturing employment will fall in response to higher local sales tax rates. As discussed above, this is because local government officials have little incentive to zone for manufacturing and also because retailing may crowd out manufacturing since both use sites with similar characteristics. ${ }^{13}$

Table 3, Panel A, gives summary statistics for our county-level sample. All sales tax rates are the sum of the state plus local sales tax rates. The neighboring sales tax rates in the county-level sample are a weighted average of the sales tax rates in all bordering counties, using the length of the border with each neighboring county as weights. ${ }^{14}$ Sales tax rates in Florida ranged from $6.0 \%$ to $7.5 \%$ during our sample period, while sales tax rates in the neighboring counties in Alabama and Georgia (which also use local sales taxes) ranged from $5.0 \%$ to $7.0 \% .^{15}$ The table also shows that employment levels vary widely. For example, in the county-level sample, the range is from near zero to 241,000 jobs in retailing and from near zero to 112,000 jobs in manufacturing.

We also examine a separate sample in which counties are divided into border versus interior regions-see below.

\footnotetext{
${ }^{13}$ We would have liked to run our model on other sectors in addition to retailing and manufacturing, such as office employment and services. But in order to run our model on a particular sector, firms must be in a sector that is identified in the NETS data (where sectors in the NETS are identified by SIC codes) and the sector must also be a zoning classification so that local officials have a means of encouraging or discouraging it. Offices are a zoning classification, but office employment is not identified in the NETS data; while service employment is identified as a sector in the NETS data, but is not a zoning classification.

${ }^{14}$ We include coastline as part of the border, using the county's own tax rate as the tax rate on this border.

15 Data are from Georgia Department of Revenue (2011) and Alabama Department of Revenue (n.d.).
} 


\section{County-level Specifications and Results}

Our base case model, for the analysis of the effects of sales tax rates on county-level retail employment, is the following:

$$
\begin{aligned}
\ln R E_{c t} & =\alpha+\beta_{1} \operatorname{tax}_{c t}+\beta_{2} \operatorname{tax}_{c, t-1}+\gamma_{1} \text { neighbortax }_{c t}+\gamma_{2} \text { neighbortax }_{c, t-1} \\
& +D_{c} \delta+D_{t} \lambda+D_{c} t \theta+\varepsilon_{c t} .
\end{aligned}
$$

In equation (1), $R E_{c t}$ is retail employment in county $c$ in year $t$. The variables tax $c t$ and $\operatorname{tax}_{\mathrm{c}, t-1}$ are the sum of the state sales tax rate plus all local sales tax rates in county $c$ in the current year and the previous year, respectively, while neighbortax ${ }_{c t}$ and neighbortax $x_{c, t-1}$ are the weighted average of the same sales tax rates in county c's neighboring counties (including counties across state borders) in the current year and the previous year, respectively. $D_{c}$ and $D_{t}$ are county and year fixed effects, and $D_{c} t$ is a set of county-specific linear time trends.

The coefficients of interest are $\beta_{1}$ and $\beta_{2}$ and their sum, or the percentage change in retail employment when the sales tax rate in the current year and/or the previous year rises by one percentage point, holding neighboring counties' sales tax rates fixed. Note that because the Florida general sales tax rate was $6 \%$ throughout our sample period, all changes in sales tax rates are due to changes in local sales tax rates. Therefore what we identify is the effect of variation in local sales tax rates only, and identification comes from changes in individual counties' sales tax rates over time. The county fixed effects control for time-invariant differences between counties in unmeasured county-specific characteristics that may affect the level of retail employment, while the year fixed effects and county-specific time trends capture any national changes and local trends in retail employment. The county-specific trends, in particular, are intended to capture sources of 
endogenous variation stemming from trends in retail growth that could affect sales taxes, an issue we discuss at length in the next section. We estimate equation (1) using OLS. Robust standard errors are clustered at the county level to allow for arbitrary patterns of serial correlation within counties and for heteroscedasticity across counties.

For the county-level analysis, we report both unweighted regressions and regressions weighted by 1992 county population levels, which are closely related to county employment levels at the beginning of our sample period. ${ }^{16}$ Because county population and employment levels vary widely in Florida, the weighted estimates of how sales tax rates affect retail employment are more representative of how the average individual is affected. Moreover, the unweighted data give us some very high estimates of marginal effects, because percentage increases in employment can be very high in percentage terms when they start from a low base in small Florida counties. On the other hand, using weights in effect throws out information from small counties. ${ }^{17}$

Results of regressions explaining total retail employment are shown in Table 4A. The results in columns (1) - (2') include only the current and then the current plus lagged sales tax rates in the county. They show that total retail employment is not significantly related to sales tax rates, regardless of whether weights are used and whether we include the lagged sales tax rate in addition to the current rate. This is true for the individual coefficient estimates, as well as for the sums of the current and lagged sales tax rates, which are shown in the second-to-last row of the table. The summed effect of the current plus

\footnotetext{
${ }^{16}$ County population estimates for 1992 were supplied by the Bureau of Economic and Business Research, University of Florida.

${ }^{17}$ When we use a dataset that constructs aggregates from a sample, we normally must worry about heteroscedasticity driven by variation in the number of observations from which the aggregates are estimates. However in the case of the NETS, we have the universe of business establishments, not a sample.
} 
lagged sales tax rate on total retail employment is positive-which is consistent with fiscal zoning—but statistically insignificant. In columns (3) and (3') we add the neighboring counties' sales tax rate, both current and lagged, to isolate the effects of independent variation in local sales tax rates. The coefficients of the own local sales tax variables remain insignificant, and are largely unchanged. Thus our results suggest that fiscal zoning by counties with high local sales tax rates does not result in a significant increase in total retail employment. As noted earlier, this evidence may reflect the offsetting positive effect of fiscal zoning and negative effect of sales taxes on prices.

In Table 4B we report estimates of the same regression models, but our dependent variable is employment in big box and anchor stores only. Here the coefficient of the current sales tax rate is positive and significant at the $5 \%$ level in the weighted regression shown in column (1'), and at the $10 \%$ level in column (1). Also the combined coefficient of the current and lagged sales tax rates is positive and significant in the weighted regressions in columns (2') and (3'), regardless of whether the neighboring sales tax rate is included or not. For the latter specification, the sum of the unweighted estimates is positive and statistically significant as well (column (3)). The weighted regression results suggest that employment in big box and anchor stores rises by $15 \%$ to $17 \%$ for each percentage point increase in the local sales tax rate. In elasticity terms, the increase is around 0.9 to 1.1 . The unweighted regression results are larger, but they may be influenced by large employment changes from a small base in sparsely-populated counties (which are down-weighted in the weighted estimates). Overall, these results indicate that local officials focus their fiscal zoning efforts on big box stores and shopping centers when sales tax rates rise, and their efforts are successful. 
Another implication of the strong positive relationship between higher sales tax rates and employment in big box and anchor stores is that large retail establishments and shopping malls may crowd out smaller retail establishments in counties that impose a local sales tax. If this were true in general, it might be a contributing factor to our findings of an insignificant relationship between the local sales tax rate and total retail employment. To test this hypothesis, we estimated the effect of the local sales tax rate on total retail employment excluding employment in big box and anchor stores. The results, which are reported in Table 4C, show that retail employment net of big box and anchor store employment is not significantly related to local sales tax rates, although the point estimates are negative. These results suggest that big box/anchor stores do little to crowd out smaller stores, and that local government officials do not try to attract small stores.

Finally, Table 4D reports the results of regressions explaining manufacturing employment. The estimated effects-including the contemporaneous effects in columns (1) and (1') and the summed effects in columns (2)-(3')-are always negative, but never significant. However, in these latter specifications, the lagged effect of the sales tax rate is always significant at the $5 \%$ or $10 \%$ level. We therefore re-estimated the models with only a lagged effect. As shown in the columns (4) and (4') of the table, the estimated effect of the lagged sales tax rate is negative and significant at the $10 \%$ level in the unweighted estimates, and negative and significant at the $5 \%$ level in the weighted estimates. The point estimates suggest that when the sales tax rate rises by one percentage point, employment in manufacturing falls by $7 \%$ to $9 \%$. The implied elasticities are -0.5 to -0.6 .

Since the results are sometimes sensitive to weighting (particularly so for big box and anchor store employment, and much less so for manufacturing), they may be 
influenced by large employment changes from a small base in sparsely-populated counties. We verified this by re-estimating the models for these two employment measures with additional terms that interacted the sales tax rate and (linear and quadratic terms in) the same measure of population that we used as weights. When we did this, the estimated interactions confirmed that the key results from the county-year analyses are in fact stronger in areas with smaller baseline populations. Moreover, the results were less sensitive to whether or not we used weights, and the qualitative conclusions were the same based on the weighted and the unweighted estimates. ${ }^{18}$

\section{Threats to Identification}

The key identifying assumption for the unbiasedness of the results in Tables 4A-4D is that local sales tax rates are uncorrelated with the residuals in our equation (1) explaining retailing and manufacturing employment. The most serious threat to this assumption is the possibility that local sales tax rates could respond endogenously to changes in retail or manufacturing. For example, an exogenous increase in retailing might cause counties to raise their local sales tax rates in order to capture more revenue. In this case, the endogeneity would generate a positive bias in the estimated relationship between sales tax rates and retail (or big box/anchor) employment. However, the bias could alternately go in a negative rather than a positive direction, because an exogenous decrease in retailing might cause counties to raise their local sales tax rates in order to maintain revenues at the past level. Therefore, these possibilities could bias our results by

\footnotetext{
${ }^{18}$ These results are not reported in the tables, but are available from the authors upon request.
} 
generating spurious evidence that could be either consistent with or contrary to the fiscal zoning hypothesis. ${ }^{19}$

As noted earlier, we included county-specific time trends in the specifications in Tables $4 \mathrm{~A}-4 \mathrm{D}$ to capture the possibility that sales tax rates might have changed endogenously in response to underlying changes in employment. When we re-estimate the models without county-specific time trends, the effect of sales tax rates on total retail employment remains small, slightly positive, and insignificant; these results suggest that for overall retail employment there is not an endogeneity problem..$^{20}$ When the models for big box/anchor retail employment are estimated without county-specific trends, the estimated effects of the sales tax rate remain positive, but become smaller and insignificant. This is the opposite of what we would expect if trend growth in employment led to the adoption of higher sales tax rates, and instead is consistent with a slight tendency for tax rates to increase when trend growth is negative. The findings for big box/anchor retail employment imply that it is important to include the county-specific trends as a partial control for endogeneity. More substantively, they suggest that the positive effects of sales tax rates on big box/anchor retail employment that we find are not driven by endogeneity.

We also did a more direct analysis of whether local sales tax rates are endogenous, by testing whether lagged changes in employment are related to changes in county-level sales tax rates. In these regressions, the dependent variable is the change in the local sales tax rate and the independent variables are the first, second, and third lags of the change in total retail employment, big box/anchor employment, or manufacturing employment;

\footnotetext{
${ }^{19}$ Given that we expect retail and manufacturing to move in opposite directions, ceteris paribus, endogeneity biases in the estimates for manufacturing would be in the opposite direction.

20 These results, and others discussed in this section, are available from the authors upon request.
} 
other control variables are the same as in the main tables. ${ }^{21}$ We found no evidence that lagged changes in any of employment measures predict changes in local sales tax rates: the estimated coefficients of the lagged employment variables were small and always individually and jointly insignificant. These results provide additional evidence that local sales tax rates are not endogenously determined by changes in employment; in other words, counties do not change their sales tax rates in response to increases in total retail sales or sales in big box/anchor stores.

Overall, these additional analyses indicate that the county-level results are driven by exogenous changes in sales taxes. With this established, we next turn to evidence on the effects of sales taxes in county border areas versus county interiors.

\section{Border-Interior Specifications and Results}

Local government officials' incentives to encourage retailing may differ in interior versus border regions of counties, and evidence of such differences can help confirm and refine the fiscal zoning hypothesis. Since sales tax rates may differ on either side of county borders, consumers have an incentive to shift their shopping to the lower-tax side. This means that the price elasticity of demand will tend to be higher near county borders than in county interiors, which undermines the effectiveness of fiscal zoning in border areas. We therefore predict that the relationship between local sales tax rates and retail employment will be less positive/more negative near county borders than in county interiors. In our empirical work, we examine whether the effect of fiscal zoning on retail employment

\footnotetext{
${ }^{21}$ Since the baseline models have county fixed effects and county-specific linear time trends, in the firstdifferenced model the original county fixed effects drop out, and the county-specific time trends become county dummy variables.
} 
differs in border versus interior areas, taking account of cross-border sales tax differentials.

To construct border versus interior regions, we use ArcGIS software to determine whether each establishment in the NETS is within 1 mile of a county border, and we identify the county across the border. ${ }^{22}$ We classify each establishment as belonging to a county's interior versus its border. We further subdivide each county's border into separate regions for each neighboring county. Parts of the border that are within one mile of more than one neighboring county are deleted, so that each border region has a unique cross-border county (which may be in a different state). ${ }^{23}$ Finally, we aggregate each type of employment within each border and interior region. This procedure increases the sample size from 67 counties to 277 border or interior regions. For each border region, the neighboring sales tax rate is now the actual sales tax rate across the border, while for interior regions, the neighboring sales tax rate is set equal to the own sales tax rate. When counties border the Atlantic Ocean or the Gulf of Mexico, the border region is combined with the interior. As before, sales tax rates are the sum of the state plus local sales tax rates. Table 3, Panel B, gives summary statistics for the border-interior sample.

In the border-interior regression models, employment by sub-county region and year replaces employment by county region and year as the dependent variable, fixed effects for sub-county regions replace the county fixed effects in equation (1), and we still include interactions between a time trend and county dummies. We also create a dummy

\footnotetext{
22 The 1-mile definition is to some extent arbitrary. We wanted to define zones for which shopping across the border is nearly equivalent to shopping on one's own side of the border.

${ }^{23}$ To illustrate our procedure, suppose a county is shaped like a square with sides of 10 miles in length, and is surrounded by one county on each side, each of which is rectangular. Our procedure divides the county into nine sub-county regions: one square interior region having sides of length 8 miles, four rectangular border regions that are each one mile by 8 miles, and four square corner regions that are each one mile square. The corner regions are dropped because they border more than one neighboring county.
} 
variable that equals one for border regions and we add interactions between the border dummy and the sales tax rate. These interaction terms allow us to estimate (and test for) differences between border versus interior regions in the effects of sales tax rates on employment. We report only unweighted estimates for the border-interior regressions. Because the sub-county regions tend to be small, many individuals live and work in different regions. Thus population-based weights are less accurate in representing employment levels and weighted regressions are therefore less informative. Standard errors are clustered at the sub-county region level.

The results of the border-interior regressions explaining total retail employment are shown in Table 5A. Columns (1) - (3) repeat the earlier specifications at the sub-county region level, without interactions between the sales tax rate and border dummies. As in Table 4A, none of the sales tax rate coefficients or their sums are significant. In columns (4)-(6) we add the border dummy-sales tax rate interactions. The estimated interaction coefficients capture the difference between the effects of sales tax rates on retail employment in border versus interior regions. The estimated interaction terms are small and insignificant, whether looking at individual coefficient estimates or summed current and lagged effects. Thus they indicate no detectable difference between border versus interior regions in the effect of sales tax rates on overall retail employment.

However when we turn to employment in big box/anchor stores, in Table 5B, we find pronounced differences between border versus interior regions. Columns (4) - (6) show the key results. In column (4), the effect of the current sales tax rate on big box/anchor store employment in interior regions is positive and significant at the $5 \%$ level (the 0.405 estimate); while in columns (5) and (6), the combined effect of the current and 
lagged sales tax rate is positive and significant at the $10 \%$ or $5 \%$ level (the estimates of 0.404 and 0.483 ). In contrast, the results for border regions show that an increase in the current and lagged sales tax rate causes big box/anchor employment to fall; the estimated effect in columns (4) - (6) is around -0.15 and significant at the $5 \%$ level (the figures of $-0.150,-0.167$ and -0.148$)$.

Thus our results show that a one percentage-point increase in the sales tax rate causes big box/anchor store employment to rise by $40-48 \%$ in interior regions and to fall by $15-17 \%$ in border regions. The implied elasticities are around 3.0 and -1.1 , respectively. The fact that our estimates in interior regions are positive is contrary to the general literature on the effects of sales taxes, which almost uniformly finds negative values. ${ }^{24}$ While our point estimates are perhaps implausibly large, we also found rather large point estimates when we did not use weights in the county-level analysis of big box/anchor employment (Table 4B). Thus, although our point estimates are high, we have a high level of confidence in our qualitative conclusions.

These estimates suggest that local officials concentrate their fiscal zoning efforts on attracting big box stores and shopping centers and that their efforts are successful in interior regions, where there is no competition from across the border. But in border regions, fiscal zoning is either counter-productive or it simply cannot overcome the negative effect of tax-induced price increases in the presence of cross-border competition.

Finally, Table 5C reports results of the border-interior analysis for manufacturing. Interestingly, the results are the opposite of those we found for retail employment at big box/anchor stores. Looking again at columns (4) - (6), the estimated interaction between

${ }^{24}$ See Wasylenko (1997) for a survey. 
the sales tax rate and the border dummy is positive and, for the current tax rate, significant. Computing the implied effects in border and interior regions, we find that an increase in the sales tax rate has a negative effect on manufacturing employment in interior regions (significant only in column (6)) and a positive effect in border regions. The estimated effects in border regions are never significant, but the differences between border and interior regions are strongly significant. Although this evidence is statistically weaker than the evidence for big box/anchor store employment, it is consistent with the existence of tradeoffs between employment in shopping centers versus employment in manufacturing. Thus fiscal zoning leads to both increased big box/anchor store employment and reduced manufacturing employment in interior regions. These results presumably reflect the fact that land in interior regions is more valuable for generating sales tax revenue, since there is less competition from retailing in neighboring counties. ${ }^{25}$

Finally, the 1-mile width that we used to define border areas is somewhat arbitrary; our idea was to isolate areas very close to county borders where nearby residents would not regard cross-county travel as costly. In order to explore the sensitivity of our results to how we defined the borders, we re-estimated the same specifications as in Tables 5A-C, but redefined the border regions to be 2 miles wide. The resulting estimates were qualitatively similar, although statistically weaker.

\footnotetext{
25 Endogeneity is less of a concern for the border-interior analysis, because these smaller regions clearly have less influence over sales tax rates. Consistent with this expectation, when we estimated the key specifications from Tables 4A-4D excluding the county time trends, the qualitative conclusions were unchanged, although the significance of some of the estimates changes.
} 


\section{Conclusion}

We have three main findings. First, total retail employment is not significantly affected by local sales tax rates. Second, however, local sales tax rates have a strong positive effect on employment in big box stores and department stores that anchor shopping centers. And third, local sales tax rates have a negative effect on manufacturing employment, although our evidence on the latter point is weaker statistically.

Our results suggest that local officials concentrate their fiscal zoning efforts on attracting large stores and shopping centers. This is presumably because these stores generate high sales tax revenues, both directly and indirectly by attracting small stores. These stores also require large sites, which means that they need the types of zoning changes that local officials can provide. In contrast, the types of stores that occupy downtown or "main street" locations are less likely to require zoning changes.

We also find that the effects of fiscal zoning on employment in big box/anchor stores differ substantially in border versus interior regions of counties. Fiscal zoning has strong positive effects in interior regions, but not in border regions. This may be because shoppers in interior regions are captive, making it easier for local officials to attract retail development despite higher tax rates. But in border regions, tax competition appears to be more important, making local officials' efforts less productive.

Manufacturing provides a cleaner test of the effects of fiscal zoning, because it competes with retailing for land, but does not have the contaminating direct price effect that pulls in the opposite direction. Our results suggest that sales taxes have the opposite effects on manufacturing employment as on big box/anchor store employment, so that local officials' efforts to attract shopping centers crowd out manufacturing. 
Our evidence feeds into a larger debate about the effects of using different types of taxes to fund local government. Over the past several decades, many states have moved to limit local governments' reliance on property taxes-their traditional funding source-and substitute other sources of revenue, including local sales taxes. Florida is among the states that have done so. ${ }^{26}$ But while property taxes give local governments an incentive to encourage all non-residential land uses, local sales taxes give them an incentive to favor retailing in particular. Our results provide empirical evidence that when sales tax rates are higher, local governments use fiscal zoning to encourage retailing and discourage manufacturing. But this type of behavior may make area residents worse off, since retailing jobs tend to pay less than manufacturing jobs.

${ }^{26}$ See Advisory Commission on Intergovernmental Relations (1995) for information on property tax limitation measures in all U.S. states. Florida adopted a property tax limitation measure in 1992 that prevents property assessments from rising by more than the minimum of the inflation rate or 3\% per year. 


\section{References}

Advisory Commission on Intergovernmental Relations. 1995. Tax and Expenditure Limits on Local Governments. M-194 (March).

Alabama Department of Revenue. n.d. Sales, Use, Lodging and Rental Tax Rates - Detail Report, https://www.revenue.alabama.gov/salestax/sales/index.cfm (viewed January 25, 2011).

Epple, Dennis, and Allan Zelenitz, 1981. Implications of Competition Across Jurisdictions: Does Tiebout Need Politics? Journal of Political Economy 89:6, 1197-1217.

Fischel, William A. 1992. Property Taxation and the Tiebout Model: Evidence for the Benefit View of Zoning and Voting, Journal of Economic Literature 31:1, 171-177.

Florida Department of Revenue. 2010. History of Local Sales Taxes and Current Rates, https://taxlaw.state.fl.us/wordfiles/SUT\%20TRC\%20HISTORY.pdf (viewed September 16, 2010).

Florida Legislative Committee on Intergovernmental Relations. 2009.2009 Local Government Financial Information Handbook, www.floridalcir.gov/UserContent/docs/File/reports/lgfih09.pdf (viewed September 8, 2010).

Florida Legislative Committee on Intergovernmental Relations. 2003.2003 Local Government Financial Information Handbook, http://www.floridalcir.gov/UserContent/docs/File/reports/lgfih03.pdf (viewed March 31, 2010).

Fulton, W. 1998. Twenty Years of Proposition 13; Tax-Cutting Initiative Shaped Planning and Development in State, California Planning and Development Report, 13:6, http://www.cp-dr.com/node/1606 (viewed September 8, 2010).

Georgia Department of Revenue. 2011. Sales and Use Tax - Historical Chart, https://etax.dor.ga.gov/salestax/salestaxrates/LGS_2011_Jan_Rate_Chart_Historical .pdf (viewed January 25, 2011).

Goolsbee, Austan, and Jonathan Zitran. 1999. Evaluating the Costs and Benefits of Taxing Internet Commerce, National Tax Journal 52:3, 413-428.

Gordon, Roger, and Wei Li. Forthcoming. Provincial and Local Governments in China: Fiscal Institutions and Government Behavior, in Capitalizing China, J. Fan and R. Morck, eds., NBER and the University of Chicago Press.

Hawkins, Richard, and Matthew N. Murray. 2004. Explaining Interjurisdictional Variations in Local Sales Tax Yield, Public Finance Review 32:1, 82-104.

King, Dale M. 2010. Three Areas Eyed for Annexation to Boca Would Net City \$2.5 Million, Says Consultant, The Boca Raton Tribune, June 16, http://www.bocaratontribune.com/three-areas-eyed-for-annexation-to-bocawould-net-city-2-5-million-says-consultant/ (viewed March 30, 2011).

Kolko, Jed, and David Neumark. 2007. Business Location Decisions and Employment Dynamics in California, San Francisco, CA: Public Policy Institute of California. 
LeRoy, Greg. 2005. The Great American Jobs Scam, San Francisco: Berrett-Koehler Publishers, Inc.

Lewis, Paul G., 2001. Retail Politics: Local Sales Taxes and the Fiscalization of Land Use, Economic Development Quarterly 15:1, 21-35.

Lewis, Paul G., and Elisa Barbour. 1999. California Cities and the Local Sales Tax, San Francisco, CA: Public Policy Institute of California.

Mark, Stephen T., Teresa McGuire, and Leslie Papke. 2000. The Influences of Taxes on Employment and Population Growth: Evidence from the Washington, D.C. Metropolitan Area, National Tax Journal 53:1, 105-24.

Mazzolari, Francesca, and David Neumark. Forthcoming. Immigration and Product Diversity, Journal of Population Economics.

Misczynski, Dean J. 1986. The Fiscalization of Land Use, in California Policy Choices, J.J. Kirlin and D.R. Winkler, eds., Sacramento, CA: School of Public Administration, University of Southern California, 127-50.

Neumark, David, Junfu Zhang, and Brandon Wall. 2007. Employment Dynamics and Business Relocation: New Evidence from the National Establishment Time Series, Research in Labor Economics 26, 39-84.

Ohls, James C., Richard Chadbourn Weisberg, and Michelle J. White. 1974. The Effect of Zoning on Land Value, Journal of Urban Economics 1:4, 428-44.

Oyston, Joyce. 2007. Largest Shopping Malls in the U.S., http://www.sutie101.com/content/largest-shopping-malls-in-the-us-a27524 (viewed September 16, 2010).

Schrag, Peter. 1998. Paradise Lost: California's Experience, America's Future, Berkeley, CA: University of California Press.

Shoer Roth, Daniel. 2010. Annexation Opponents Destined to Repeat Pleas, Miami Herald, April 6, http://www.miamiherald.com/2010/04/06/1564987/annexationopponents-destined.html (viewed March 30, 2011).

Sonstelie, John C., and Paul R. Portney. 1978. Profit Maximizing Communities and the Theory of Local Public Expenditure, Journal of Urban Economics 5:2, 263-277.

U.S. Census Bureau, Annual Surveys of State and Local Government, www2.census.gov/govs/estimate/ (viewed September 14, 2010).

Wasylenko, Michael. 1997. Taxation and Economic Development: The State of the Economic Literature, New England Economic Review March/April, 37-52.

White, Michelle J. 1975. Suburban Zoning in Fragmented Metropolitan Areas, in Fiscal Zoning and Land Use Controls, E.S. Mills and W.E. Oates, eds., Lexington, MA: D. C. Heath, 31-100. 
Table 1.A: Number of Florida Counties Imposing Local Sales Taxes

\begin{tabular}{|c|c|c|c|c|c|c|c|c|}
\hline \multirow{2}{*}{$\begin{array}{l}\text { Year } \\
1992\end{array}$} & \multicolumn{2}{|c|}{$\begin{array}{c}\text { All Local } \\
\text { Sales Taxes }\end{array}$} & \multicolumn{2}{|c|}{$\begin{array}{l}\text { Infrastructure } \\
\text { or Small } \\
\text { County Surtax }\end{array}$} & \multicolumn{2}{|c|}{$\begin{array}{c}\text { School } \\
\text { Capital } \\
\text { Outlay Tax }\end{array}$} & $\begin{array}{c}\text { Indigent Care, } \\
\text { Trauma } \\
\text { Center, or } \\
\text { Hospital Tax }\end{array}$ & $\begin{array}{c}\text { Charter } \\
\text { County } \\
\text { Transit } \\
\text { System Tax }\end{array}$ \\
\hline & & $(.87)$ & 32 & $(.91)$ & 0 & (0) & $(.50)$ & $(.50)$ \\
\hline 1993 & 37 & $(.93)$ & 34 & $(.97)$ & 0 & $(0)$ & $(.50)$ & $(.50)$ \\
\hline 1994 & 42 & $(.94)$ & 39 & $(.97)$ & 0 & (0) & $(.50)$ & $(.50)$ \\
\hline 1995 & 47 & $(.91)$ & 44 & $(.94)$ & 0 & $(0)$ & $(.50)$ & $(.50)$ \\
\hline 1996 & 50 & $(.96)$ & 46 & $(.98)$ & 3 & $(.42)$ & $(.50)$ & $(.50)$ \\
\hline 1997 & 51 & $(.95)$ & 47 & $(.97)$ & 4 & $(.44)$ & $(.50)$ & $(.50)$ \\
\hline 1998 & 50 & $(.98)$ & 46 & $(.97)$ & 7 & $(.45)$ & $(.38)$ & $(.50)$ \\
\hline 1999 & 52 & $(.95)$ & 46 & $(.96)$ & 8 & $(.50)$ & $(.38)$ & $(.50)$ \\
\hline 2000 & 50 & $(.97)$ & 44 & $(.98)$ & 8 & $(.50)$ & $(.38)$ & $(.50)$ \\
\hline 2001 & 50 & $(.97)$ & 45 & $(.96)$ & 8 & $(.50)$ & $(.41)$ & $(.50)$ \\
\hline 2002 & 51 & $(.97)$ & 45 & $(.97)$ & 9 & $(.50)$ & $(.50)$ & $(.50)$ \\
\hline 2003 & 54 & $(.97)$ & 46 & $(.96)$ & 13 & $(.50)$ & $(.50)$ & $(.50)$ \\
\hline 2004 & 54 & $(.96)$ & 45 & $(.97)$ & 13 & $(.50)$ & $(.50)$ & $(.50)$ \\
\hline 2005 & 58 & $(.94)$ & 45 & $(.97)$ & 16 & $(.50)$ & $(.44)$ & $(.50)$ \\
\hline 2006 & & $(.94)$ & 46 & $(.96)$ & 16 & $(.50)$ & $(.44)$ & $(.50)$ \\
\hline
\end{tabular}

Notes: Figures in parentheses are the average local sales tax rate for counties that impose each local sales tax. Sources: State of Florida Department of Revenue (2010), and Florida Legislative Committee on Intergovernmental Relations (2009). 
Table 1.B: Local Sales Tax Rate Changes in Florida, 1993-2006

\begin{tabular}{|c|c|c|c|c|c|}
\hline \multicolumn{7}{|c|}{ Total number of counties changing their tax rates } \\
\hline Year & $\begin{array}{c}\text { Aggregate } \\
\text { Local Sales } \\
\text { Tax Rate }\end{array}$ & $\begin{array}{c}\text { Infrastructure } \\
\text { Tax or Small } \\
\text { County Tax }\end{array}$ & $\begin{array}{c}\text { School } \\
\text { Capital } \\
\text { Outlay Tax }\end{array}$ & $\begin{array}{c}\text { Indigent Care, } \\
\text { Trauma } \\
\text { Center, or } \\
\text { Hospital Tax }\end{array}$ & $\begin{array}{c}\text { Charter } \\
\text { County } \\
\text { Transit } \\
\text { System Tax }\end{array}$ \\
\hline 1993 & 9 & 9 & 0 & 0 & 0 \\
\hline 1994 & 7 & 7 & 0 & 0 & 0 \\
\hline 1995 & 9 & 9 & 0 & 0 & 0 \\
\hline 1996 & 8 & 6 & 3 & 0 & 0 \\
\hline 1997 & 4 & 2 & 2 & 0 & 0 \\
\hline 1998 & 6 & 2 & 4 & 1 & 0 \\
\hline 1999 & 5 & 4 & 2 & 0 & 0 \\
\hline 2000 & 2 & 2 & 0 & 0 & 0 \\
\hline 2001 & 3 & 2 & 0 & 1 & 0 \\
\hline 2002 & 5 & 3 & 1 & 1 & 0 \\
\hline 2003 & 7 & 4 & 4 & 0 & 1 \\
\hline 2004 & 3 & 1 & 2 & 0 & 0 \\
\hline 2005 & 6 & 2 & 3 & 2 & 0 \\
\hline 2006 & 1 & 1 & 0 & 0 & 0 \\
\hline
\end{tabular}

Sources: State of Florida Department of Revenue (2010), and Florida Legislative Committee on Intergovernmental Relations (2009). 
Table 2: Florida County Sales Tax Rates, 1992-2006

\begin{tabular}{|c|c|c|}
\hline County & 1992 rate & Changes \\
\hline Alachua & 0 & $1 \%$ in 2002,0 in $2003, .25 \%$ in 2005 \\
\hline Baker & 0 & $1 \%$ in 1994 \\
\hline Bay & $0.50 \%$ & $1 \%$ in $1994, .5 \%$ in $1995,1 \%$ in $1998, .5 \%$ in 2004 \\
\hline Bradford & $1 \%$ & \\
\hline Brevard & 0 & \\
\hline Broward & 0 & \\
\hline Calhoun & 0 & $1 \%$ in 1993 \\
\hline Charlotte & 0 & $.75 \%$ in $1995,1 \%$ in 2006 \\
\hline Citrus & 0 & \\
\hline Clay & $1 \%$ & \\
\hline Collier & 0 & \\
\hline Columbia & 0 & $1 \%$ in 1994 \\
\hline Desoto & $1 \%$ & \\
\hline Dixie & $1 \%$ & \\
\hline Duval & $0.50 \%$ & $1 \%$ in 2001 \\
\hline Escambia & $0.58 \%$ & $1 \%$ in $1993,1.5 \%$ in 2000 \\
\hline Flagler & $1 \%$ & \\
\hline Franklin & 0 & \\
\hline Gadsden & $1 \%$ & \\
\hline Gilchrist & $0.25 \%$ & $1 \%$ in 1993 \\
\hline Glades & $1 \%$ & \\
\hline Gulf & 0 & $.25 \%$ in $1997, .5 \%$ in $1998,1 \%$ in 2006 \\
\hline Hamilton & $1 \%$ & \\
\hline Hardee & $1 \%$ & \\
\hline Hendry & $1 \%$ & \\
\hline Hernando & 0 & $.5 \%$ in 1999,0 in $2004, .5 \%$ in 2005 \\
\hline Highlands & $1 \%$ & \\
\hline Hillsborough & $0.50 \%$ & $.94 \%$ in $1997, .75 \%$ in $1998, .81 \%$ in $2001,1 \%$ in 2002 \\
\hline Holmes & 0 & $1 \%$ in 1995 \\
\hline Indian River & $1 \%$ & \\
\hline Jackson & $0.5 \%$ & 0 in $1993, .58 \%$ in $1995,1.25 \%$ in $1996,1.5 \%$ in 1997 \\
\hline Jefferson & $1 \%$ & \\
\hline Lafayette & $1 \%$ & \\
\hline Lake & $1 \%$ & \\
\hline Lee & 0 & \\
\hline Leon & $1 \%$ & $1.5 \%$ in 2003 \\
\hline Levy & $0.25 \%$ & $1 \%$ in 1993 \\
\hline Liberty & 0 & $1 \%$ in 1993 \\
\hline Madison & $1 \%$ & \\
\hline Manatee & $1 \%$ & 0 in $1993, .5 \%$ in $1994,1 \%$ in $1995, .5 \%$ in 1999,0 in $2000, .5$ in 2003 \\
\hline Marion & 0 & $1 \%$ in $2003, .5 \%$ in 2005 \\
\hline Martin & 0 & $.583 \%$ in $1996, .417 \%$ in 1997,0 in $1998,1 \%$ in 1999,0 in 2002 \\
\hline Miami-Dade & $0.50 \%$ & $1 \%$ in 2003 \\
\hline Monroe & $1 \%$ & $1.5 \%$ in 1996 \\
\hline Nassau & 0 & $.5 \%$ in 1994,0 in $1995,1 \%$ in 1996 \\
\hline Okaloosa & 0 & $.42 \%$ in $1995,1 \%$ in $1996, .58 \%$ in 1999,0 in 2000 \\
\hline Okeechobee & 0 & $.25 \%$ in $1995,1 \%$ in 1996 \\
\hline Orange & 0 & $.5 \%$ in 2003 \\
\hline Osceola & $1 \%$ & \\
\hline
\end{tabular}




\begin{tabular}{|l|c|l|}
\hline County & 1992 rate & \multicolumn{1}{|c|}{ Changes } \\
\hline Palm Beach & 0 & $.5 \%$ in 2005 \\
\hline Pasco & 0 & $1 \%$ in 2005 \\
\hline Pinellas & $1 \%$ & \\
\hline Polk & 0 & $.5 \%$ in $2004,1 \%$ in 2005 \\
\hline Putnam & 0 & $1 \%$ in 2003 \\
\hline Saint Johns & 0 & \\
\hline Saint Lucie & 0 & $.5 \%$ in 1996 \\
\hline Santa Rosa & 0 & $.33 \%$ in $1993,1 \%$ in $1994, .79 \%$ in $1998, .5 \%$ in 1999 \\
\hline Sarasota & $1 \%$ & \\
\hline Seminole & $1 \%$ & $.75 \%$ in $2001,1 \%$ in 2002 \\
\hline Sumter & $1 \%$ & \\
\hline Suwannee & $1 \%$ & \\
\hline Taylor & $1 \%$ & \\
\hline Union & 0 & $1 \%$ in 1993 \\
\hline Volusia & 0 & $.5 \%$ in 2002 \\
\hline Wakulla & $1 \%$ & \\
\hline Walton & 0 & $1 \%$ in 1995 \\
\hline Washington & 0 & $1 \%$ in 1994 \\
\hline
\end{tabular}

Sources: State of Florida Department of Revenue (various years). 
Table 3: Summary Statistics

\begin{tabular}{|l|c|c|c|c|}
\hline \multicolumn{5}{|c|}{ A. County-Level } \\
\hline Variable & Mean & Std. Dev. & Min. & Max. \\
\hline $\begin{array}{l}\text { Sales tax rate, local plus state, } \\
\text { current }\end{array}$ & 6.70 & 0.458 & 6.0 & 7.5 \\
\hline $\begin{array}{l}\text { Sales tax rate, local plus state, } \\
\text { lagged }\end{array}$ & 6.69 & 0.461 & 6.0 & 7.5 \\
\hline $\begin{array}{l}\text { Neighboring sales tax rate, } \\
\text { current }\end{array}$ & 6.65 & 0.301 & 5.69 & 7.27 \\
\hline $\begin{array}{l}\text { Neighboring local sales tax rate, } \\
\text { lagged }\end{array}$ & 6.64 & 0.305 & 5.66 & 7.27 \\
\hline Total retail employment & 22,670 & 38,744 & 81 & 240,868 \\
\hline $\begin{array}{l}\text { Big box/anchor retail } \\
\text { employment }\end{array}$ & 1,678 & 2,720 & 1 & 16,975 \\
\hline Manufacturing employment & 9,912 & 18,804 & 25 & 111,510 \\
\hline \multicolumn{1}{|c|}{ Border and Interior Regions } & & 7.5 \\
\hline $\begin{array}{l}\text { Sales tax rate, local plus state, } \\
\text { current }\end{array}$ & 6.69 & 0.465 & 6.0 & 7.5 \\
\hline $\begin{array}{l}\text { Sales tax rate, local plus state, } \\
\text { lagged }\end{array}$ & 6.68 & 0.468 & 6.0 & 7.5 \\
\hline $\begin{array}{l}\text { Neighboring sales tax rate, } \\
\text { current }\end{array}$ & 6.61 & 0.527 & 5.0 & 7.5 \\
\hline $\begin{array}{l}\text { Neighboring sales tax rate, } \\
\text { lagged }\end{array}$ & 6.61 & 0.524 & 5.0 & 219,529 \\
\hline Total retail employment & 5,520 & 19,835 & 2 & 14,928 \\
\hline $\begin{array}{l}\text { Big box/anchor retail } \\
\text { employment }\end{array}$ & 411 & 1,428 & 1 & 109,190 \\
\hline Manufacturing employment & 2,377 & 9,617 & 1 & \\
\hline
\end{tabular}

Notes: In Panel A, there are 1,005 county-year observations (15 years of data for 67 counties) on the contemporaneous variables, and 938 county-year observations (14 years of data for 67 counties) on the lagged variables. In Panel B, there are 4,155 locality-year observations (15 years of data for border and interior regions of each county), and 3,878 locality-year observations on the lagged variables. Border regions extend one mile inward from county borders; their construction is explained in Section VII. 
Table 4A: Regression Results Explaining Total Retail Employment, County-Level Analysis

\begin{tabular}{|l|c|c|c|c|c|c|}
\hline \multirow{2}{*}{$\begin{array}{l}\text { Explanatory } \\
\text { variables }\end{array}$} & $(1)$ & $\left(1^{\prime}\right)$ & $(2)$ & $\left(2^{\prime}\right)$ & $(3)$ & $\left(3^{\prime}\right)$ \\
\cline { 2 - 7 } & Unwgt. & Wgt. & Unwgt. & Wgt. & Unwgt. & Wgt. \\
\hline $\begin{array}{l}\text { Sales tax rate, } \\
\text { current }\end{array}$ & $\begin{array}{l}0.016 \\
(0.017)\end{array}$ & $\begin{array}{c}0.002 \\
(0.016)\end{array}$ & $\begin{array}{c}-0.014 \\
(0.015)\end{array}$ & $\begin{array}{c}-0.017 \\
(0.012)\end{array}$ & $\begin{array}{c}-0.013 \\
(0.020)\end{array}$ & $\begin{array}{c}-0.005 \\
(0.013)\end{array}$ \\
\hline $\begin{array}{l}\text { Sales tax rate, } \\
\text { lagged }\end{array}$ & - & - & $\begin{array}{c}0.030 \\
(0.021)\end{array}$ & $\begin{array}{c}0.019 \\
(0.013)\end{array}$ & $\begin{array}{c}0.028 \\
(0.021)\end{array}$ & $\begin{array}{c}0.014 \\
(0.012)\end{array}$ \\
\hline $\begin{array}{l}\text { Neighboring sales } \\
\text { tax rate, current }\end{array}$ & - & - & - & - & $\begin{array}{c}-0.010 \\
(0.056)\end{array}$ & $\begin{array}{c}-0.059 \\
(0.020)\end{array}$ \\
\hline $\begin{array}{l}\text { Neighboring sales } \\
\text { tax rate, lagged }\end{array}$ & - & - & - & - & 0.011 & 0.023 \\
$(0.023)$ & $(0.014)$ \\
\hline $\begin{array}{l}\text { Effect of a unit increase in current plus } \\
\text { lagged sales tax rate }\end{array}$ & $\begin{array}{c}0.016 \\
(0.024)\end{array}$ & $\begin{array}{c}0.002 \\
(0.019)\end{array}$ & $\begin{array}{c}0.015 \\
(0.023)\end{array}$ & $\begin{array}{c}0.009 \\
(0.020)\end{array}$ \\
\hline \begin{tabular}{l}
$\mathrm{R}^{2}$ \\
\hline
\end{tabular}
\end{tabular}

The dependent variable is the log of total retail employment. There are 1,005 observations for the contemporaneous specifications, and 938 observations for the specifications with lags. The sales tax rate variable is the sum of the local sales tax plus the $6 \%$ general Florida sales tax, measured in units of 0-100. All specifications include county and year fixed effects, and countytime trend interactions. Standard errors are clustered at the county level. 1992 population levels are used as weights in the columns labeled "Wgt." 
Table 4B: Regression Results Explaining Retail Employment at Big Box and Anchor Stores, County-Level Analysis

\begin{tabular}{|c|c|c|c|c|c|c|}
\hline \multirow{2}{*}{$\begin{array}{l}\text { Explanatory } \\
\text { variables }\end{array}$} & (1) & $\left(1^{\prime}\right)$ & (2) & (2') & (3) & $\left(3^{\prime}\right)$ \\
\hline & Unwgt. & Wgt. & Unwgt. & Wgt. & Unwgt. & Wgt. \\
\hline $\begin{array}{l}\text { Sales tax rate, } \\
\text { current }\end{array}$ & $\begin{array}{c}0.208 \\
(0.113)\end{array}$ & $\begin{array}{c}0.134 \\
(0.056)\end{array}$ & $\begin{array}{c}0.047 \\
(0.090)\end{array}$ & $\begin{array}{c}0.080 \\
(0.049)\end{array}$ & $\begin{array}{l}-0.004 \\
(0.177)\end{array}$ & $\begin{array}{c}0.074 \\
(0.053)\end{array}$ \\
\hline $\begin{array}{l}\text { Sales tax rate, } \\
\text { lagged }\end{array}$ & - & - & $\begin{array}{c}0.256 \\
(0.224)\end{array}$ & $\begin{array}{c}0.085 \\
(0.044)\end{array}$ & $\begin{array}{c}0.313 \\
(0.233)\end{array}$ & $\begin{array}{c}0.076 \\
(0.048)\end{array}$ \\
\hline $\begin{array}{l}\text { Neighboring sales } \\
\text { tax rate, current }\end{array}$ & - & - & - & - & $\begin{array}{c}0.293 \\
(0.534)\end{array}$ & $\begin{array}{c}0.029 \\
(0.102)\end{array}$ \\
\hline $\begin{array}{l}\text { Neighboring sales } \\
\text { tax rate, lagged }\end{array}$ & $\begin{array}{ll}- & -1 \\
\end{array}$ & - & - & - & $\begin{array}{l}-0.288 \\
(0.225)\end{array}$ & $\begin{array}{c}0.033 \\
(0.072)\end{array}$ \\
\hline \multicolumn{3}{|c|}{$\begin{array}{l}\text { Effect of a unit increase in current plus } \\
\text { lagged local sales tax rate }\end{array}$} & $\begin{array}{c}0.303 \\
(0.192)\end{array}$ & $\begin{array}{c}0.166 \\
(0.064)\end{array}$ & $\begin{array}{c}0.309 \\
(0.135)\end{array}$ & $\begin{array}{c}0.150 \\
(0.063)\end{array}$ \\
\hline $\mathrm{R}^{2}$ & 0.98 & 0.98 & 0.98 & 0.98 & 0.98 & 0.99 \\
\hline
\end{tabular}

The dependent variable is the log of the sum of big box and anchor store employment. See the text for a list of stores. Other details from notes to Table 4A apply here. 
Table 4C: Regression Results Explaining Total Retail Employment Excluding Big Box and Anchor Store Retail Employment, County-Level Analysis

\begin{tabular}{|l|c|c|c|c|c|c|}
\hline \multirow{2}{*}{$\begin{array}{l}\text { Explanatory } \\
\text { variables }\end{array}$} & $(1)$ & $\left(1^{\prime}\right)$ & $(2)$ & $\left(2^{\prime}\right)$ & $(3)$ & $\left(3^{\prime}\right)$ \\
\cline { 2 - 7 } & Unwgt. & Wgt. & Unwgt. & Wgt. & Unwgt. & Wgt. \\
\hline Sales tax rate, & -0.0006 & -0.008 & -0.022 & -0.025 & -0.016 & -0.012 \\
current & $(0.014)$ & $(0.014)$ & $(0.014)$ & $(0.011)$ & $(0.015)$ & $(0.011)$ \\
\hline $\begin{array}{l}\text { Sales tax rate, } \\
\text { lagged }\end{array}$ & - & - & 0.014 & 0.015 & 0.011 & 0.010 \\
\hline $\begin{array}{l}\text { Neighboring sales } \\
\text { tax rate, current }\end{array}$ & - & - & - & - & -0.032 & -0.064 \\
\hline $\begin{array}{l}\text { Neighboring sales } \\
\text { tax rate, lagged }\end{array}$ & - & - & - & - & 0.022 & $0.014)$ \\
\hline $\begin{array}{l}\text { Effect of a unit increase in current plus } \\
\text { lagged sales tax rate }\end{array}$ & -0.008 & -0.010 & -0.005 & $0.014)$ & -0.002 \\
\hline$R^{2}$ & 0.99 & 0.99 & 0.99 & 0.99 & $0.013)$ & 0.019 \\
\hline
\end{tabular}

The dependent variable is the log of total retail employment excluding big box and anchor store retail employment. Other details from notes to Table $4 \mathrm{~A}$ apply here. 
Table 4D: Regression Results Explaining Manufacturing Employment, County-Level Analysis

\begin{tabular}{|c|c|c|c|c|c|c|c|c|}
\hline \multirow{2}{*}{$\begin{array}{l}\text { Explanatory } \\
\text { variables }\end{array}$} & (1) & $\left(1^{\prime}\right)$ & (2) & $\left(2^{\prime}\right)$ & (3) & $\left(3^{\prime}\right)$ & (4) & $\left(4^{\prime}\right)$ \\
\hline & Unwgt. & Wgt. & Unwgt. & Wgt. & Unwgt. & Wgt. & Unwgt. & Wgt. \\
\hline $\begin{array}{l}\text { Sales tax rate, } \\
\text { current }\end{array}$ & $\begin{array}{l}-0.037 \\
(0.041)\end{array}$ & $\begin{array}{l}-0.023 \\
(0.029)\end{array}$ & $\begin{array}{c}0.025 \\
(0.032)\end{array}$ & $\begin{array}{c}0.008 \\
(0.023)\end{array}$ & $\begin{array}{c}0.034 \\
(0.042)\end{array}$ & $\begin{array}{l}-0.003 \\
(0.025)\end{array}$ & & \\
\hline $\begin{array}{l}\text { Sales tax rate, } \\
\text { lagged }\end{array}$ & - & 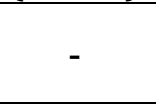 & & & & & & $\begin{array}{l}-0.070 \\
(0.033)\end{array}$ \\
\hline $\begin{array}{l}\text { Neigl } \\
\text { tax } \mathrm{r}\end{array}$ & - & - & & & & $\begin{array}{c}0.043 \\
(0.041)\end{array}$ & & $\begin{array}{c}0.041 \\
(0.036)\end{array}$ \\
\hline $\begin{array}{l}\text { Neighboring sales } \\
\text { tax rate, lagged }\end{array}$ & - & - & - & - & $\begin{array}{c}0.081 \\
(0.079)\end{array}$ & $\begin{array}{c}0.065 \\
(0.045)\end{array}$ & $\begin{array}{c}0.075 \\
(0.082)\end{array}$ & $\begin{array}{c}0.066 \\
(0.047)\end{array}$ \\
\hline \multicolumn{3}{|c|}{$\begin{array}{l}\text { Effect of a unit increase in current } \\
\text { plus lagged local sales tax rate }\end{array}$} & $\begin{array}{l}-0.059 \\
(0.058)\end{array}$ & $\begin{array}{l}-0.043 \\
(0.037) \\
\end{array}$ & $\begin{array}{c}-0.068 \\
(0.068)\end{array}$ & $\begin{array}{c}-0.071 \\
(0.042) \\
\end{array}$ & & \\
\hline R-Squared & 0.99 & 0.99 & 0.99 & 0.99 & 0.99 & 0.99 & 0.99 & 0.99 \\
\hline
\end{tabular}

The dependent variable is the log of manufacturing employment. Other details from notes to Table $4 \mathrm{~A}$ apply here. 
Table 5A: Regression Results Explaining Total Retail Employment, Border-Interior Analysis, 1-Mile Border Zones

\begin{tabular}{|c|c|c|c|c|c|c|}
\hline Explanatory variables & (1) & (2) & (3) & (4) & (5) & (6) \\
\hline Sales tax rate, current & $\begin{array}{l}-0.032 \\
(0.049)\end{array}$ & $\begin{array}{l}-0.046 \\
(0.047)\end{array}$ & $\begin{array}{l}-0.037 \\
(0.056)\end{array}$ & $\begin{array}{l}0.020 \\
(0.077)\end{array}$ & $\begin{array}{l}-0.050 \\
(0.061)\end{array}$ & $\begin{array}{l}-0.021 \\
(0.092)\end{array}$ \\
\hline Sales ti & - & $\begin{array}{c}0.028 \\
(0.047)\end{array}$ & $\begin{array}{c}0.038 \\
(0.057)\end{array}$ & & $\begin{array}{c}0.045 \\
(0.066)\end{array}$ & $\begin{array}{c}0.073 \\
(0.095)\end{array}$ \\
\hline $\begin{array}{l}\text { Sales ta } \\
\text { border }\end{array}$ & - & - & - & $\begin{array}{l}-0.067 \\
(0.092)\end{array}$ & $\begin{array}{c}0.005 \\
(0.078)\end{array}$ & $\begin{array}{l}-0.019 \\
(0.088)\end{array}$ \\
\hline $\begin{array}{l}\text { te, lagged, } x \\
\text { nmy }\end{array}$ & - & - & - & - & $\begin{array}{l}-0.023 \\
(0.084)\end{array}$ & $\begin{array}{l}-0.042 \\
(0.095)\end{array}$ \\
\hline $\begin{array}{l}\text { Neighboring sales tax rate, } \\
\text { current }\end{array}$ & - & - & $\begin{array}{l}-0.027 \\
(0.060)\end{array}$ & - & 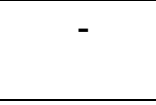 & $\begin{array}{l}-0.030 \\
(0.066)\end{array}$ \\
\hline $\begin{array}{l}\text { Neighboring sales tax rate, } \\
\text { lagged }\end{array}$ & - & - & $\begin{array}{l}-0.026 \\
(0.060)\end{array}$ & - & & $\begin{array}{l}-0.033 \\
(0.066)\end{array}$ \\
\hline \multicolumn{2}{|c|}{$\begin{array}{l}\text { Effect of a unit increase in current plus } \\
\text { lagged sales tax rate (in columns }\left(2^{\prime}\right) \\
\left.\text { and ( } 3^{\prime}\right) \text {, results are for interior } \\
\text { regions) }\end{array}$} & $\begin{array}{l}-0.018 \\
(0.070)\end{array}$ & $\begin{array}{c}0.001 \\
(0.084)\end{array}$ & - & $\begin{array}{l}-0.005 \\
(0.096)\end{array}$ & $\begin{array}{c}0.052 \\
(0.133)\end{array}$ \\
\hline \multicolumn{4}{|c|}{$\begin{array}{l}\text { Effect of a unit increase in current sales tax rate on } \\
\text { employment in border regions (main effect plus interaction) }\end{array}$} & $\begin{array}{l}-0.047 \\
(0.057)\end{array}$ & - & - \\
\hline \multicolumn{5}{|c|}{$\begin{array}{l}\text { Effect of a unit increase in current plus lagged sales tax rate on } \\
\text { employment in border regions (main effects plus interactions) }\end{array}$} & $\begin{array}{l}-0.022 \\
(0.080)\end{array}$ & $\begin{array}{l}-0.009 \\
(0.086)\end{array}$ \\
\hline \multicolumn{5}{|c|}{$\begin{array}{l}\text { Difference in effect of current plus lagged sales tax rate between border } \\
\text { and interior regions (sum of border interactions) }\end{array}$} & $\begin{array}{l}-0.017 \\
(0.111)\end{array}$ & $\begin{array}{l}-0.061 \\
(0.122)\end{array}$ \\
\hline $\mathrm{R}^{2}$ & 0.99 & 0.99 & 0.99 & 0.99 & 0.99 & 0.99 \\
\hline
\end{tabular}

The dependent variable is the log of total retail employment. There are 4,155 observations for the contemporaneous specifications, and 3,878 observations for the specifications with lags. The sales tax rate variable is the sum of the local sales tax plus the 6\% general Florida sales tax, measured in units of 0-100. All regressions include fixed effects for each sub-county area (each unique border area and county interior), year fixed effects, and county-time trend interactions. Standard errors are clustered at the sub-county region level. Estimates are not weighted. 
Table 5B: Regression Results Explaining Big Box and Anchor Store Retail Employment, Border-Interior Analysis, 1-Mile Border Zones

\begin{tabular}{|c|c|c|c|c|c|c|}
\hline Explanatory variables & (1) & $(2)$ & (3) & $(4)$ & (5) & (6) \\
\hline Sales tax rate, current & $\begin{array}{c}-0.022 \\
(0.058)\end{array}$ & $\begin{array}{c}-0.031 \\
(0.042)\end{array}$ & $\begin{array}{l}-0.025 \\
(0.037)\end{array}$ & $\begin{array}{c}0.405 \\
(0.179)\end{array}$ & $\begin{array}{l}-0.017 \\
(0.150)\end{array}$ & $\begin{array}{c}0.011 \\
(0.153)\end{array}$ \\
\hline Sales tax rate, lagged & & $\begin{array}{l}-0.006 \\
(0.070)\end{array}$ & $\begin{array}{l}-0.018 \\
(0.064)\end{array}$ & & $\begin{array}{c}0.419 \\
(0.261)\end{array}$ & $\begin{array}{c}0.472 \\
(0.270)\end{array}$ \\
\hline $\begin{array}{l}\text { Sales tax rate, current, } \mathrm{x} \\
\text { border dummy }\end{array}$ & - & - & - & $\begin{array}{l}-0.556 \\
(0.189)\end{array}$ & $\begin{array}{l}-0.015 \\
(0.164)\end{array}$ & $\begin{array}{l}-0.039 \\
(0.168)\end{array}$ \\
\hline $\begin{array}{l}\text { Sales tax rate, lagged, } \mathrm{x} \\
\text { border dummy }\end{array}$ & - & - & - & 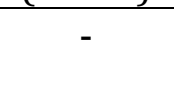 & $\begin{array}{l}-0.554 \\
(0.269)\end{array}$ & $\begin{array}{l}-0.594 \\
(0.275)\end{array}$ \\
\hline $\begin{array}{l}\text { Neighboring sales tax rate, } \\
\text { current }\end{array}$ & - & - & $\begin{array}{l}-0.029 \\
(0.053)\end{array}$ & - & - & $\begin{array}{l}-0.029 \\
(0.047)\end{array}$ \\
\hline $\begin{array}{l}\text { Neighboring sales tax rate, } \\
\text { lagged }\end{array}$ & - & - & $\begin{array}{c}0.041 \\
(0.062)\end{array}$ & - & - & $\begin{array}{l}-0.060 \\
(0.054)\end{array}$ \\
\hline \multicolumn{2}{|c|}{$\begin{array}{l}\text { Effect of a unit increase in current plus } \\
\text { lagged sales tax rate (interior in } \\
\left.\text { columns }\left(2^{\prime}\right) \text { and }\left(3^{\prime}\right)\right)\end{array}$} & $\begin{array}{l}-0.037 \\
(0.080)\end{array}$ & $\begin{array}{l}-0.039 \\
(0.078)\end{array}$ & - & $\begin{array}{c}0.404 \\
(0.226)\end{array}$ & $\begin{array}{c}0.483 \\
(0.240)\end{array}$ \\
\hline \multicolumn{4}{|c|}{$\begin{array}{l}\text { Effect of a unit increase in current sales tax rate on } \\
\text { employment in border regions (main effect plus interaction) }\end{array}$} & $\begin{array}{l}-0.150 \\
(0.056)\end{array}$ & - & - \\
\hline \multicolumn{5}{|c|}{$\begin{array}{l}\text { Effect of a unit increase in current plus lagged sales tax rate on } \\
\text { employment in border regions (main effects plus interactions) }\end{array}$} & $\begin{array}{l}-0.167 \\
(0.070)\end{array}$ & $\begin{array}{l}-0.148 \\
(0.069)\end{array}$ \\
\hline \multicolumn{5}{|c|}{$\begin{array}{l}\text { Difference in effect of current plus lagged sales tax rate between border } \\
\text { and interior regions (sum of border interactions) }\end{array}$} & $\begin{array}{l}-0.569 \\
(0.226)\end{array}$ & $\begin{array}{l}-0.631 \\
(0.237)\end{array}$ \\
\hline $\mathrm{R}^{2}$ & 0.96 & 0.96 & 0.96 & 0.96 & 0.96 & 0.96 \\
\hline
\end{tabular}

The dependent variable is the log of the sum of big box and anchor store retail employment. Other details from notes to Table 5A apply here. 
Table 5C: Regression Results Explaining Manufacturing Employment, Border-Interior Analysis, 1-Mile Border Zones

\begin{tabular}{|c|c|c|c|c|c|c|}
\hline Explanatory variables & (1) & $(2)$ & (3) & $(4)$ & (5) & (6) \\
\hline Sales tax rate, current & $\begin{array}{c}0.074 \\
(0.076)\end{array}$ & $\begin{array}{c}0.080 \\
(0.075)\end{array}$ & $\begin{array}{c}0.066 \\
(0.080)\end{array}$ & $\begin{array}{l}-0.185 \\
(0.123)\end{array}$ & $\begin{array}{l}-0.162 \\
(0.097)\end{array}$ & $\begin{array}{l}-0.278 \\
(0.133)\end{array}$ \\
\hline Sales tax rate, lagged & - & $\begin{array}{l}-0.027 \\
(0.063)\end{array}$ & $\begin{array}{l}-0.029 \\
(0.071)\end{array}$ & - & $\begin{array}{l}-0.090 \\
(0.107)\end{array}$ & $\begin{array}{l}-0.091 \\
(0.145)\end{array}$ \\
\hline $\begin{array}{l}\text { Sales tax rate, current, } \mathrm{x} \\
\text { border dummy }\end{array}$ & - & - & - & $\begin{array}{c}0.337 \\
(0.157)\end{array}$ & $\begin{array}{c}0.312 \\
(0.131)\end{array}$ & $\begin{array}{c}0.417 \\
(0.161)\end{array}$ \\
\hline $\begin{array}{l}\text { Sales tax rate, lagged, } \mathrm{x} \\
\text { border dummy }\end{array}$ & - & - & - & - & $\begin{array}{c}0.084 \\
(0.137)\end{array}$ & $\begin{array}{c}0.070 \\
(0.164)\end{array}$ \\
\hline $\begin{array}{l}\text { Neighboring sales tax rate, } \\
\text { current }\end{array}$ & - & - & $\begin{array}{c}0.050 \\
(0.104)\end{array}$ & - & - & $\begin{array}{c}0.119 \\
(0.117)\end{array}$ \\
\hline $\begin{array}{l}\text { Neighboring sales tax rate, } \\
\text { lagged }\end{array}$ & - & - & $\begin{array}{l}-0.003 \\
(0.064)\end{array}$ & - & - & $\begin{array}{c}0.007 \\
(0.074)\end{array}$ \\
\hline \multicolumn{2}{|c|}{$\begin{array}{l}\text { Effect of a unit increase in current plus } \\
\text { lagged sales tax rate (interior in } \\
\left.\text { columns }\left(2^{\prime}\right) \text { and }\left(3^{\prime}\right)\right)\end{array}$} & $\begin{array}{c}0.053 \\
(0.107)\end{array}$ & $\begin{array}{c}0.037 \\
(0.118)\end{array}$ & - & $\begin{array}{l}-0.253 \\
(0.154)\end{array}$ & $\begin{array}{l}-0.370 \\
(0.174)\end{array}$ \\
\hline \multicolumn{4}{|c|}{$\begin{array}{l}\text { Effect of a unit increase in current sales tax rate on } \\
\text { employment in border regions (main effect plus interaction) }\end{array}$} & $\begin{array}{c}0.151 \\
(0.094)\end{array}$ & - & - \\
\hline \multicolumn{5}{|c|}{$\begin{array}{l}\text { Effect of a unit increase in current plus lagged sales tax rate on } \\
\text { employment in border regions (main effects plus interactions) }\end{array}$} & $\begin{array}{c}0.143 \\
(0.126)\end{array}$ & $\begin{array}{c}0.118 \\
(0.131)\end{array}$ \\
\hline \multicolumn{5}{|c|}{$\begin{array}{l}\text { Difference in effect of current plus lagged sales tax rate between border } \\
\text { and interior regions (sum of border interactions) }\end{array}$} & $\begin{array}{c}0.400 \\
(0.189)\end{array}$ & $\begin{array}{c}0.487 \\
(0.197)\end{array}$ \\
\hline $\mathrm{R}^{2}$ & 0.97 & 0.97 & 0.97 & 0.97 & 0.97 & 0.97 \\
\hline
\end{tabular}

The dependent variable is the log of manufacturing employment. Other details from notes to Table 5A apply here. 